\title{
Identification and Occurrence of Perfect Stage and Cultural and Morphological Variants of Colletotrichum gloeosporioides from Guava in Puerto Rico'
}

\author{
Lii-Jang Liu ${ }^{2}$
}

\section{INTRODUCTION}

Guava (Psidium guajava L.) is a common fruit in Puerto Rico and other parts of tropical America. The demand for this fruit is increasing locally. Growers now are therefore much interested in establishing commercial guava plantings. Almost all varieties and clones of guava available in Puerto Rico for this purpose are unfortunately susceptible to some degree to a fruit rot presumably caused by Glomerella cingulata (Ston.) Spaulding and Schrenk. The actual causal agent of the so-called Glomerella disease, however, has not been established. Studies were undertaken recently to isolate and identify the causal agent or agents from affected fruits. Perithecia were formed when different isolates oi Colletolrichum from guava were placed in eulture media. The sexual stage of this fungus had not been obtained previously from guava in vitro in Puerto Rico. The following description thus constitutes the first of its isolation. Variations in conidia morphology, as well as the cultural appearance and physiology of the isolates, also are included.

\section{REVIEW OF LITERATURE}

Sheldon (4) in 1906 was the first to describe a fungus isolated from mummified fruits of guava. He gave it the name Gilesporium psidii. Toro (5) in 1922 reported that Gleosporium musarum Cooke and Massee, the causal agent of banana anthracnose, also affected a number of tropical fruits including guava. He realized however that the conidia of Gleosporium musarum did not correspond to those of Gleosporium psidii from guava. He also reported the presence of several biological forms of conidia of various sizes. Nolla (2) in 1926 reported Colletotrichum gloeosporioides Penz as the cause of anthracnose discase of mango, orange, grapefruit, lemon, avocado, and lime. Schrenk and Spaulding (3) in 1903 suggested the name Glomerelia as a synonym for Gleosporium. Glomerella psidii (Del) Sheldon was listed

1 Manuscript submitted to Editorial Board August. 12, 1971.

2 Phytopathologist, Agricultural Experiment Station, Mayagüez Campus, University of Puerto Rico, Río Piedras, P.R. Thanks are due to Mrs. Julia Rodriguez for assistance in temperature studies, Mrs. Amelia Cortes-Monllor in pH studies, and Mr. Arcángel Rodríguez in spore size measurement. 

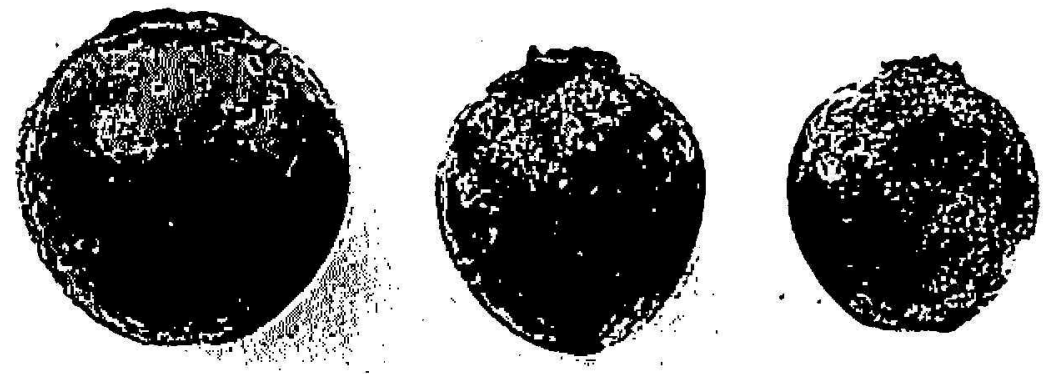

Frg. 1.-Whitish mycelial mass and black discoloration on guava fruits caused by Colletotrichum gloeosporioides: From left to right, healthy fruit and diseased fruits.

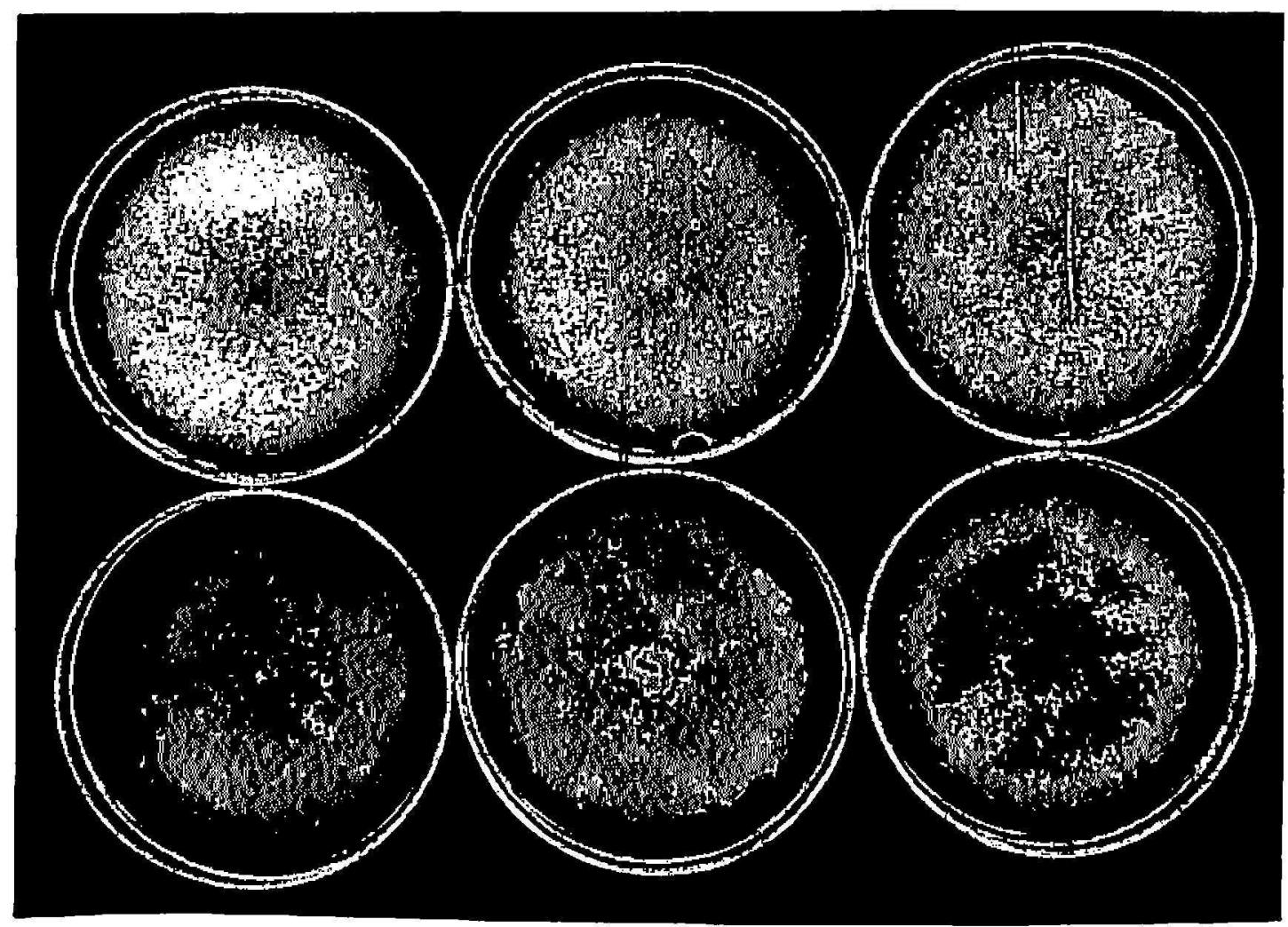

Fig. 2.-Cultural appearance of six isolates of Colletolrichum gloeosporiodes on potato dextrose agar: From top down, left to right, 1st row, G 1, G 3, and G 5 (light strains); 2nd row, G 7, G 9 (light strains), and G 10 (dark strain). 

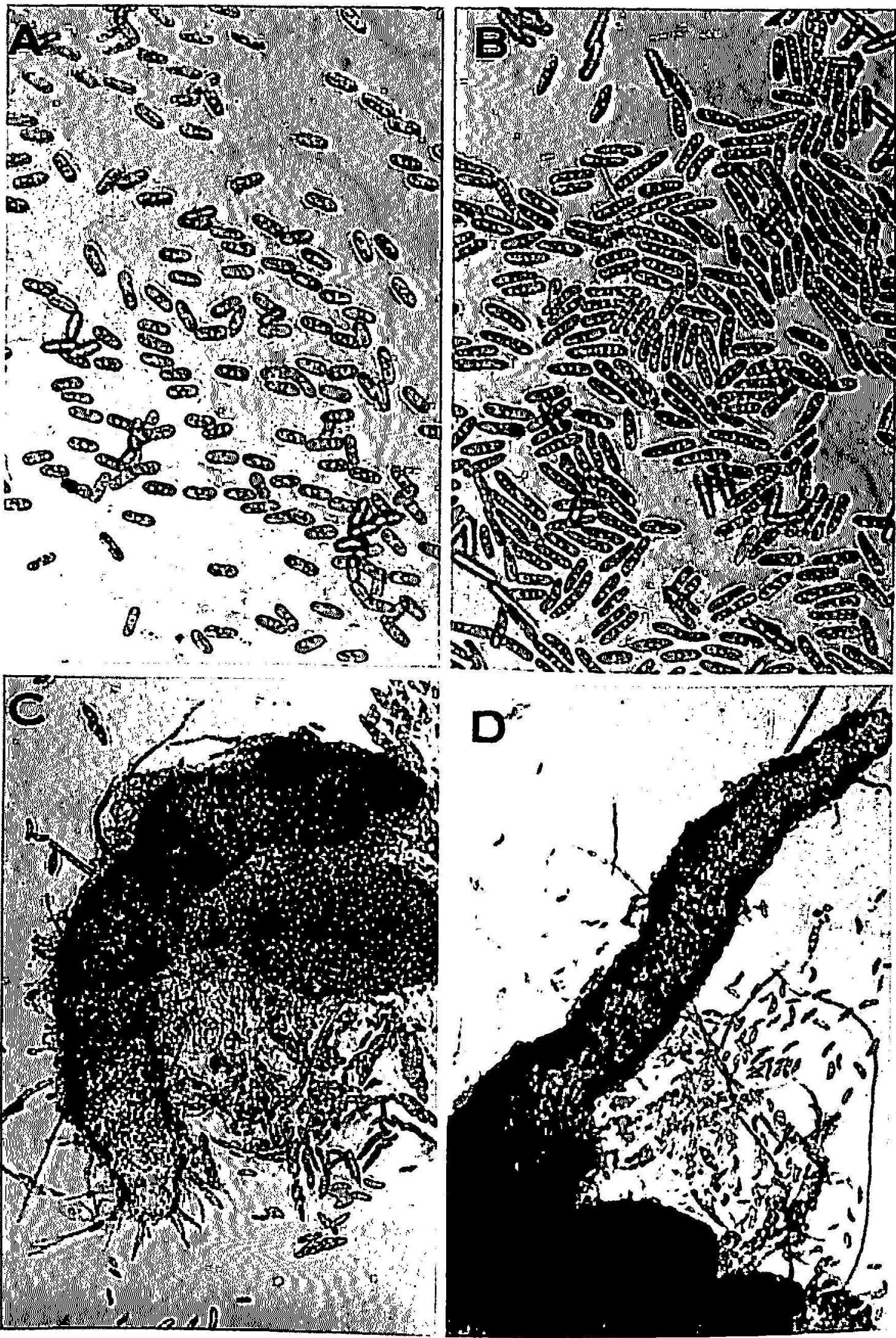

FIG. 3. Conidia and perithecia of Colletotrichum gloeosporioides grown on artificial medium (potato dextrose agar): A, conidia (light st rain), B, conidia (dark strain) C and $\mathrm{D}$, perithecia with elongated neck. 
(1) in 1960 as a synonym for $G$. cingulata (Ston.) Spaulding and Schrenk and Colletotrichum gloeosporioides Penz as a conidial stage of Glomerella cingulata. No information is available concerning the identification and occurrence of the perfect stage Colletotrichum gloeosporioides on Puerto Rican guava.

\section{METHODS AND RESULTS}

\section{DESCRIPTION OF SYMP'TOMS}

In the early stage of infection, affected guava fruits show small dark brown circular spots under the skin. When the spots are one-half inch or more across, whitish mycelium appears on their surface. As the fungus pene-

TABLE 1.-Frequency of distribution and size of conidia of isolates of Colletotrichum gloeosporioides from guata

\begin{tabular}{c|c|c|c|c|c|c|c}
\hline \multicolumn{2}{c|}{ Dark strain (G 10) } & \multicolumn{4}{|c}{ Light strain (G 9) } \\
\hline Length & Conidia & Width & Conidia & Length & Conidia & Width & Conidia \\
\hline Microns & Ntumber & Microns & Number & Microns & Number & Microns & Number \\
$14.50-16.40$ & 0 & $4.50-6.40$ & 452 & $14.50-16.40$ & 0 & $4.50-6.40$ & 39 \\
$16.50-18.40$ & 0 & $6.50-8.40$ & 48 & $16.50-18.40$ & 396 & $6.50-8.40$ & 388 \\
$18.50-20.40$ & 98 & $8.50-10.40$ & 0 & $18.50-20.40$ & 104 & $8.50-10.40$ & 23 \\
$20.50-22.40$ & 96 & & & $20.50-22.40$ & 0 & & \\
$22.50-24.40$ & 170 & & & $22.50-24.40$ & 0 & & \\
$24.50-26.40$ & 29 & & & $24.50-26.40$ & 0 & & \\
$26.50-28.40$ & 39 & & & $26.50-28.40$ & 0 & & \\
$28.50-30.40$ & 22 & & & $28.50-30.40$ & 0 & & \\
$30.50-32.40$ & 12 & & & $30.50-32.40$ & 0 & & \\
$32.50-34.40$ & 20 & & & $32.50-34.40$ & 0 & & \\
$34.50-36.40$ & 2 & & & $34.50-36.40$ & 0 & & \\
$36.50-38.40$ & 6 & & & $36.50-38.40$ & & & \\
\hline
\end{tabular}

trates more and more into the guava tissue, the invaded area becomes enlarged, until finally the entire fruit is involved. At this stage, the entire fruit has turned dark in color and papery in texture. Pink pustules, which are masses of conidia, appear on the surface of the affected fruits (fig. 1).

\section{CULTURAL AND MORPHOLOGICAL VARIANTS}

Six isolates of Colletotrichum were obtained from affected guava fruits. Monoconidial cultures of these isolates were prepared in potato dextrose agar (PDA). Of these isolates, one dark and five light strains appeared consistently when cultured on PDA (fig. 2). The conidia produced by the dark strain were also consistently longer than those produced by the light strains (fig. 3, A, and B). The conidia of the dark strain were mostly oblong, some slightly curved, 18.50 to $38.40 \mu$ long by 4.50 to $8.40 \mu$ wide. Those 
of the light strains were mostly cylindrical, 16.50 to $20.40 \mu$ long by 4.50 to $10.40 \mu$ wide (table 1).

Both dark and light strains isolated from guava were grown in the following five different agar cultural media: malt, potato dextrose, nutrient, corn meal, and bean pod. As shown in table 2 , the conidia varied in size significantly (at 1-percent level) in the different media. The largest conidia were produced in malt agar, the smallest in nutrient agar. However, data obtained from Duncan Multiple Range Test (table 3) show that conidial

TABLE 2.-E Elect of cullural media on size of conidia of

Colletotrichum gloeosporioides from guava

\begin{tabular}{lccccc}
\hline & \multicolumn{4}{c}{ Size of conidia } \\
\cline { 2 - 3 } \cline { 5 - 6 } \cline { 5 - 6 } & \multicolumn{2}{c}{ Length } & \multicolumn{2}{c}{ Width } \\
\cline { 2 - 3 } \cline { 5 - 6 } Mark strain & Light strain & & Dark strain & Light strain \\
\hline Potato dextrose agar & Microns & Microns & & Microns & Microns \\
Nutrient agar & 21.42 & 17.30 & & 6.72 & 8.22 \\
Corn meal agar & 21.75 & 16.35 & & 5.85 & 6.60 \\
Bean pod agar & 14.95 & 16.60 & & 6.52 & 7.80 \\
& 18.82 & 18.80 & & 6.37 & 7.57 \\
& 16.80 & 16.62 & & 6.17 & 6.92 \\
\hline
\end{tabular}

${ }^{1}$ Average of 450 conidia.

T.ввц. 3.--Statistical romparison of size of conidia of

Colletot richum glocosporioides from guava

\begin{tabular}{lcc}
\hline Origin & \multicolumn{2}{c}{ Spore size } \\
\cline { 2 - 3 } & Length & Width \\
Fungi & $F$ & $F$ \\
Cultural media & $35.6264^{* * 1}$ & $111.9276^{* * 1}$ \\
Fungi X media & $28.6046^{* *}$ & $18.3103^{* *}$ \\
\hline
\end{tabular}

1** Significant at 1-percent level.

spore size differed significantly between the dark and the light strains when cultured in different media. Although there are interactions between the length of the conidia and the cultural media (significant at 1-percent level), this sime relationship was not established when the width of the conidia was used for interaction studies.

in VITRO Formation OF PERFECT STAGE

Fertile perithecia were formed in 4 to 7 days at $20^{\circ}$ to $24^{\circ} \mathrm{C}$. when monoconidial cultures of the isolates (all strains) were grown together on PDA supplemented with a 1-percent extract of guava fruit. Perithecia were also 

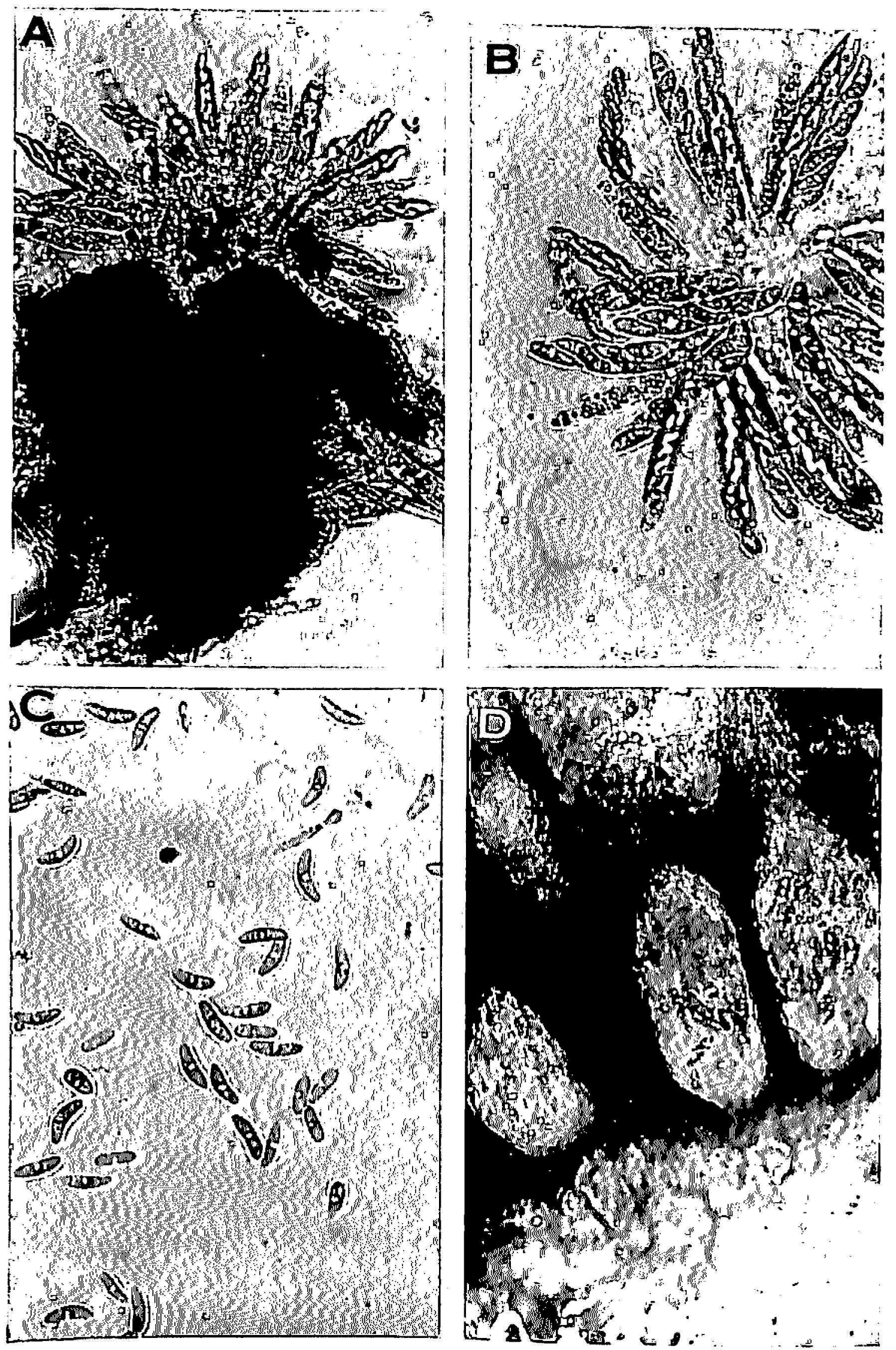

FIg. 4. Perfect stage of Colletotrichum glocosporioides grown on infected guava fruits: A, Perithecium, B, asci, C, ascospores, and D, perithecia immersed in infected tissues of gltava fruits. 
obtained when the same isolates were grown alone. Monoascosporic cultures of the isolates were prepared in PDA. Ascospore isolations consistently resulted in the recovery of typical $C$. gloeosporioides culture. Perithecia were immersed and more or less compounded subspherical in a 7- to 10-day old culture. The neck of the perithecia became elongated in an older artificial culture (fig. 3, C, and D). Perithecia obtained from both the dark and the light strains of Colletotrichum grown on guava fruits were $430 \mu$ to $630 \mu$ long by $157 \mu$ to $210 \mu$ wide. Asci werc subclavate, often slightly pedicellate, $41 \mu$ to $61 \mu$ long by $12 \mu$ to $12.50 \mu$ wide. Ascospores were allantoid, hyaline, $16.4 \mu$ to $21.3 \mu$ long by $6.1 \mu$ to $8.2 \mu$ wide (fig. 4 ).

\section{PHYSIOLOGIC CHARACTERISTICS}

\section{Effect of Temperature on Myeclial Growth}

Two monoconidial isolates of Colletotrichum spp. (G 9 and 10) from guava were grown in PDA at $12^{\circ}, 16^{\circ}, 20^{\circ}, 24^{\circ}, 28^{\circ}, 32^{\circ}, 36^{\circ}$, and $40^{\circ} \mathrm{C}$. For each temperature, four petri dishes containing $15 \mathrm{ml}$. of the above-mentioned medium were inoculated with $2 \mathrm{~mm}$. culture dises. The dises were cut with a sterile cork borer from the advancing margin of colonies kept in potato dextrose agar. The dishes containing the inoculum were incubated at the different temperatures for 7 days. The increase in the diameter of the colonies was measured at the end of the incubation period.

The results show that the optimum temperature range for mycelial growth of one of the isolates of Colletotrichum (G 9) from guava lies between $28^{\circ}$ and $32^{\circ} \mathrm{C}$. on the medium used. The optimum temperature range for the other isolate (G 10) from guava lies between $24^{\circ}$ and $28^{\circ} \mathrm{C}$.

\section{Effect of pH on Mycelial Grouth}

Two monoconidial isolates of Colletotrichum spp. (G 9 and 10) were grown on potato dextrose agar with the following $\mathrm{pH}: 3,5,5.6,7,9$, and 11. For each $\mathrm{pH}$, five petri dishes containing $15 \mathrm{ml}$. of the above-mentioned medium were inoculated with $2 \mathrm{~mm}$. culture dises of the Colletotrichum spp., cut with a sterile cork borer from the advancing margin of the colonies kept in the same medium. The dishes containing the inoculum were incubated at $28^{\circ} \mathrm{C}$. for 4 days. The increase in the diameter of the colonies was measured at the end of the incubation period.

The results indicated that the optimum $\mathrm{pH}$ for mycelial growth of Colletotrichum spp. (G 10) lies between 5 and 7 (fig. 5). Similar results were obtained with isolate G 9.

\section{PATHOGENICITY TESTS}

Detached guava fruits of six varioties, i.e., P.R. 2 (Trujillo 2), P.R. 3 (Cibuco 3), P.R. 5 (D-18), P.R. 6 (D-20), P.R. 4 (D-13), and P.R. 7 
(57-8-141) were first surface-stcrilized with 95-percent alcohol for 5 minutes, then sprayed with a spore suspension of the isolates of Colletotrichum obtained from guava. Non-inoculated fruits were used as controls. The inoculated fruits were left in polyethylene bags at room temperature (approximately $20^{\circ}$ to $22^{\circ} \mathrm{C}$.). Two days after inoculation, small black spots appeared on the surface of the inoculated fruits of varicties P.R. 2, P.R.3, P.R. 5, and P.R. 7. The spots enlarged until the entire fruit was covered. Pink masses appeared on the affected areas 4 days after inoculation. When inoculated fruits were left in a round polyethylene incubation chamber,

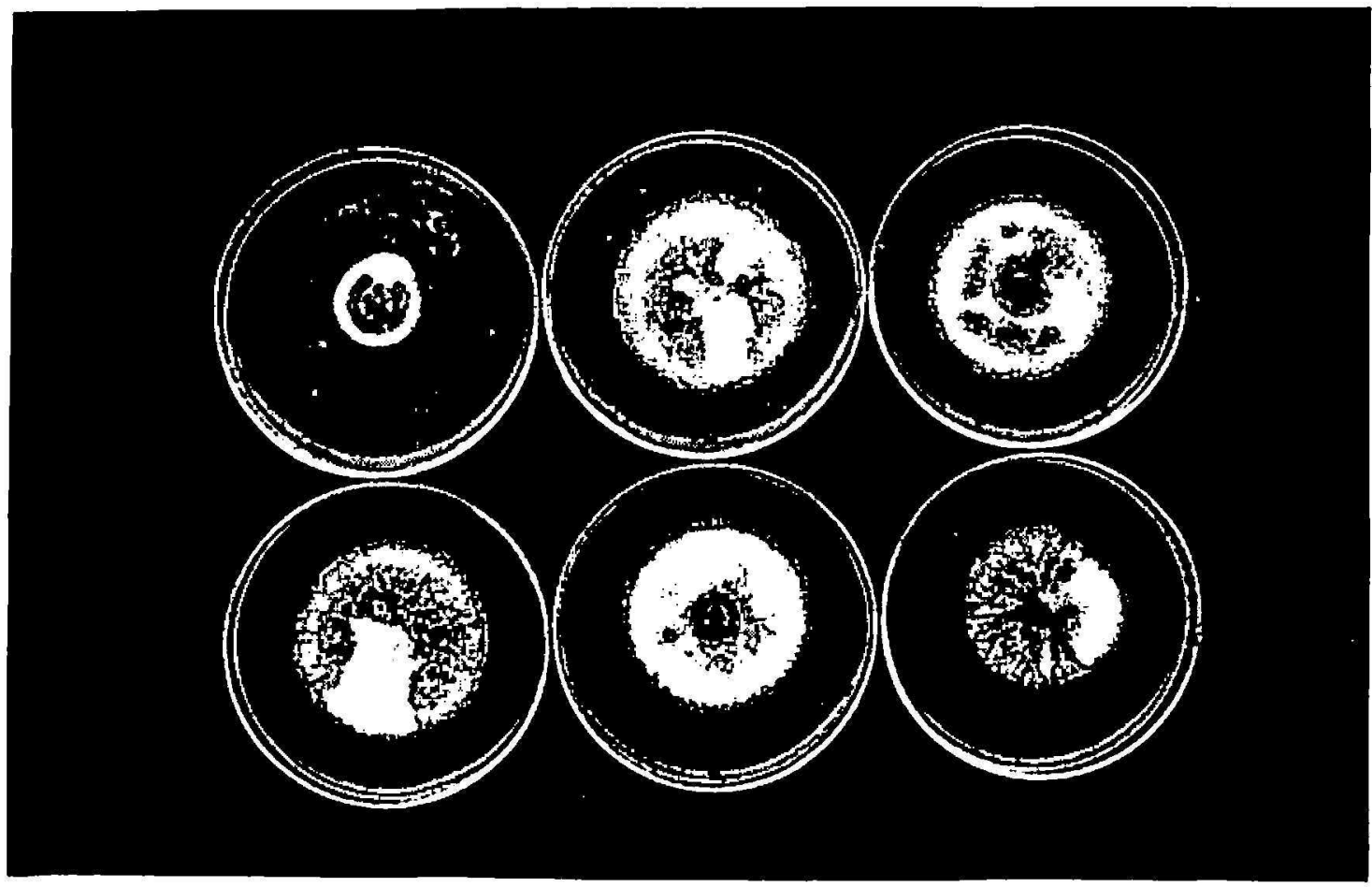

Fig. 5.-Growth of Colletolrichum glocosporioides (G 10) on potato dextrose agar at various $\mathrm{pH}$ : From left to right, 1 st row $\mathrm{pH} 3,5.0,5.6 ; 2$ nd row $\mathrm{pH} 7,9$, and 11 , respectively.

black, immersed perithecia appeared around the pink masses 7 to 10 days after inoculation. The non-inoculated fruits remained healthy. The infection was rated by scoring each fruit from 1 to 3 . A score of 1 indicated freedom from black spots and the score advaneed with an increase in the severity of the infection.

Table 4 indicates degree of resistance.

\section{DISCUSSION AND CONCLUSION}

The results of these investigations agree in general with those of Toro (5) in that among the isolates of Colletolichum spp. there were biological forms in which conidia varied in size. Despite the fact that the size of the 
conidia varies with the cultural redia, the media is of importance in the separation of biologic forms on a spore-size basis. At least two morphologically and culturally distinct strains (one dark and one light) of Colletotrichum spp. have been isolated from affected fruits of Puerto Rican guava.

Perithecia were formed when these isolates were grown together or alone in potato dextrose agar. The perithecia, asci, and ascospores produced by both strains were typical of those of Glomerella cingulata as described by Schrenk and Spaulding (3). Beaked perithecia were not found in young cultures or in affected fruits. However, beaked perithecia were found in older cultures grown on potato dextrose agar (an artificial medium).

Conidia produced by the dark strain were significantly longer than those produced by the light strain but their perithecia were indistinguishable.

TABLE 4. Pahogenicily of Colletotrichum gloeosporioides on guava fruits

\begin{tabular}{ccc}
\hline Variety & Fruits infected & Infection \\
\hline P.R. 2 (Trujillo 2) & Percent & Degree \\
P.R. 3 (Cibuco 3) & 71.1 & $3^{\mathbf{1}}$ \\
P.R. 5 (D-18) & 14.2 & 1 \\
P.R. 6 (D-20) & 14.2 & 1 \\
P.R. 4 (D-13) & 0 & 0 \\
P.R. 7 (57-8-141) & 0 & 0 \\
\end{tabular}

1 Infection types: 0, no symptoms; 1 , resistant (many small lesions); 2, moderately resistant (moderate amount of overlapping lesions); and 3, susceptible (many overlapping lesions).

Both strains thus have been identified as Colletotrichum gloeosporioides or Gilomerella cingulata.

Perithecia of $C$. gloeosporioides have not been reported previously on guava in Puerto Rico.

Guava varietics P.R. ( 3 and P.R. 4 exhibit a degree of resistance to G. gloeosporioides. Breeding for resistant varietics thus furnishes a new approach to the possible control of this disease.

\section{SUMMARY}

Two strains of Colletotrichum spp., one dark and one light, were isolated from diseased fruits of guava in Puerto Rico. The isolates differ in cultural appearance, physiologic characteristics, and size of conidia. The optimum temperature range for mycelial growth of the dark strain lies between $24^{\circ}$ and $28^{\circ} \mathrm{C}$. The optimum temperature range for the light strain lies between $28^{\circ}$ and $32^{\circ} \mathrm{C}$. The optimum $\mathrm{pH}$ range for both strains lie between 5 and 7 . Perithecia were produced when the dark strain was crossed with the light 
strain, or grown alone in potato dextrose agar at $24^{\circ}$ to $28^{\circ} \mathrm{C}$. Perithecia obtained from both isolates were typical of Glomerella cingulata. Ascospore isolations consistently resulted in the recovery of typical $C$. gloeosporioides cultures. Although conidia produced by the dark strain are significantly longer than those of the light strain, their perithecia are indistinguishable. Both strains are identified as $C$. gloeosporioides, the conidial stage of $G$. cingulala. The formation of the sexual stage of $C$. gloeosporioides in vitro in Puerto Rico has not been reported hitherto.

\section{RESUMEN}

Se aislaron dos cepas de Colletotrichum spp., una oscura y una clara, de guayabas atacadas por el hongo en Puerto Rico. Las cepas aisladas diferian entre si en cuanto a los aspectos del cultivo, características fisiológicas y tamaño de las conidiosporas. La gama de temperaturas óptimas para el crecimiento del micelio de la cepa oscura se extiende de $24^{\circ}$ a $28^{\circ} \mathrm{C}$., mientras que para el de la cepa clara se extiende de $28^{\circ}$ a $32^{\circ} \mathrm{C}$. La gama de valores pH para ambas cepas se extiende de 5 a 7 . Se formaron peritecios cuando la cepa oscura se cruzó con la clarn o se cultivó por sí sola en agar glucosado de papas a una temperatura de $24^{\circ}$ a $28^{\circ} \mathrm{C}$. Los peritecios formados por ambas cepas son típicos de Glomerella cingulata. Las ascosporas que se aislaron produjeron consistentemente cultivos típicos de $C$. glocosporioides. Aunque las conidiosporas producidas por la cepa oscura son significativamente más largas que las de la cepa clara, los peritecios no pueden diferenciarse entre sí. Ambas cepas se identifican como C. gloeosporioides, estado asexual de G. cingulata. Esta es la primera vez que en Puerto Rico se informa la formación in vitro del estado perfecto o sexual de $C$. glocosporioides.

\section{LITERATURE CITED}

1. Anonymous, Index of plant diseases in the United States, USDA Agricultural Handbook No. 165, 1960.

2. Nolla, J. A. B., The anthracnose of citrus fruits, mango, and avocado, J. Dept. Agr. P.R. 10 (2) : 25-63, 1926.

3. Schrenk, H. Van and Spaulding, P., The bitter rot of apples, Bur, Pl. Ind., USDA Bull. No. 44, 1903.

4. Sheldon, J. L., The ripe rot or mummy disease of guavas, Agr. Exp. Sta., Univ. W. Va., Bull. 104, 1906.

5. Turo, R. A., Studies on banana anthracnose, J. Dept. Agr. P.R. 4 (4) : 3-23, 1922. 